\title{
Moral education and development in Poland after 1989
}

\author{
Joanna Mysona Byrska
}

\begin{abstract}
This paper aims to show the development of moral education in Poland after 1989. The Catholic Church, family and schools are the most important things concerning moral education and development in Poland. . In the past, moral education in families and in state schools was different. The Catholic Church was, for many years, the anchor of freedom and Polish identity. By 1989, there were two models of education and moral development in Poland: the state model in the communist spirit and the Catholic Church with its Christian values. Individual families were in favor of one or the other. After 1989 everything changed and the state model became the same as the model of the Catholic Church and Polish families. In the paper, I will try to show how the current state of moral education in Poland and also I will try to present the changes that took place after 1989 in moral education.
\end{abstract}

Keywords: education, Poland, Catholic Church

\section{Introduction}

Education and moral development in the Polish tradition took place in three settings: the family, the Church, and the state. In view of historical events, the concepts propagated by the state regarding education and moral development differed from the philosophies presented in the family and by the Catholic Church. In regards to Poland's specific history, the Catholic Church was, for many years, the anchor of freedom and Polish identity. During the time of partitions (18th-19th centuries) the Polish state did not exist on any political maps. The Catholic Church in this period took care of both moral and patriotic education and was a space of freedom for the Polish people. The great role the Catholic Church had in the life of Poland and the Polish people, both in moral development as well as education resulted in the widespread belief that "Poland is Catholic" (Gowin, 1995).

After the World War II Poland became a Communist country. The communist and moral education proposed by the state was incompatible with the Christian values promoted by the Catholic Church and supported by many Polish families. By 1989, there were two models of education and moral development in Poland: the state model in the communist spirit and the Catholic Church with its Christian values. Individual families were in favor of one or the other. The Catholic Church was regarded as an institution which allowed freedom of thought.

After 1989 there was a broad public debate regarding which education and moral development model should be used. The model that seemed to have widespread public support was the one proposed by the Catholic Church. It was therefore necessary to restore the Church's place and importance in the public sphere as well as in education, which meant the restoration of religious education in state schools.

With the winning of independence in 1918, after almost 200 years of occupation, religion classes were held in the framework of general education in schools. But it was not consistent with 
the ideology of the communist state, which was formed in 1945 and in 1961 religion classes were definitively removed from schools (Cogiel, 2015).

Post-1989, it was believed that the issues of education and moral development fell within the domain of the Catholic Church. The education and development of younger generations should be done in the spirit of Christian values. In order to achieve this teaching, religion was again to be taught in schools. It seemed that since Polish society was predominantly Catholic to restore the teaching of religion in schools was simply a matter of course and an expression of newly recovered freedom. The case, however, proved not to be as simple as expected. With the return of religious education to schools in September 1991 ideological arguments began. These arguments were the result of questions regarding what form education in this field should take and if moral development should remain at the sole disposal of the Catholic Church in state schools as well.

Public debate regarding moral development in Poland was neither systematic nor adequately expansive. In this article I will discuss the following elements of the image of education and moral development in Poland: Restoration of religious instruction in primary schools in 1991 and its effects from today's perspective after more than a quarter of a century ( 25 years) of practice, the introduction of ethics and the introduction of the subject "education for family life". At the end of the text I will discuss the issue of 'for profit' education and which education is not conducive to the formation of attitudes that facilitate the proper functioning of democratic order.

\section{The return of religion to public schools}

Traditionally it was the Catholic Church and patriotic families who were considered to be responsible for the education and moral development of children in Poland. After regaining independence in 1918, religious education took place in all types of schools and it was mandatory for Catholics. All matters relating to the Church - state relations, including religious education were regulated by a Concordat made the Holy See in 1925 (Wisłocki, 1977).

After the World War II, the teaching of religion in school turned out to be incompatible with the communist ideology of the state that was the Polish People's Republic. The Concordat of 1925 was overturned; religious education ceased to be compulsory and in its place began the process of secularization of Polish education. Religious education was not provided for in the newly formed schools. The process of the secularization of education ended in 1961 and religious instruction was removed from state schools. Religious education was replaced by indoctrination, which was aimed at raising model citizens of the communist state.

The Polish people did not support the communist authority unanimously and much opposition arose. Similar to the time of the partition two models of ethical education began to operate simultaneously: the state, with its propaganda in public schools and the Catholic Church, which in 1961 began teaching religion to children and the youth in catechetical halls in churches. Polish society was strongly based on secularization, but the Catholic Church despite all the repression remained an important force in the People's Republic.

In this way during the communist era, there were two parallel main models of education and moral development - the state model that was consistent with the applicable communist ideology, which was secular and atheistic and the Church model of education and development in the spirit of Christian values and at the same time patriotic because the communist authorities were not seen as a government chosen by the Polish nation, but one that had been imposed as a result of political decisions taken by the victorious powers after World War II.

The year 1989 brought the long sought after freedom for the people of Poland. In place of the Polish People's Republic the Republic of Poland was created - an independent state, in which education and moral development may be instituted, in accordance with the will of the people, in 
the spirit of Christian values. It seemed that nobody in Polish society would negate the legitimacy of restoring religious instruction in high schools and primary schools of the Free State. The wider debate also seemed in this respect to be completely unnecessary. Restoration of religious education in schools was viewed as a demonstration of regaining freedom in education and moral development.

The teaching of religion in state schools was restored under the Regulation of the Ministry of National Education of 3 August 1990. The regulation emphasized the importance and role of ethical Christian values in the educational process. Attention was also drawn to the right of parents to educate their children in conformity with their own religious beliefs. The preamble to the new Education Act of 09.07.1991 was recorded as the basis for the universal ethical principles of education and development that respect the Christian system of values (Dz. U., nr 95, poz. 425, 1990). Both the restoration of religious education, as well as Christian values as the foundation of education, seemed to be the fulfillment of earlier aspirations for freedom. The restoration of teaching religion in schools was not subjected to public discussion, no referendum was held in this matter. It seemed that a Polish society, of which the vast majority declared membership in the Catholic Church would fully support the changes (Mariański, 2016).

Religious education in public schools started on $1^{\text {st }}$ September 1991 . For another year some churches, at the request of students, taught religion in their catechetical halls with the consent of the Archbishop of Krakow. This need appeared as some students viewed religions education in schools as a limitation of their freedom especially in important areas such as moral development. When religion was taught in churches students could choose the teacher. In schools the director decided who would be the instructor and the students had no say in the matter. Religion was simply one of many subjects. As one of many subjects in school, religion classes began to have problems similar to any other subject.

According to the agreement between the state and the Polish Episcopate the cost of religious instruction during the first year would be met by the Catholic Church. Religion teachers, largely clergy and religious (priests, brothers and nuns), did not receive a salary from the state for the first year, their work was remunerated by the Church according to arrangements made by the Episcopate. After the end of the first year, religious instruction in schools began to be funded by the government, the same as all other subjects. At the same time, a special Catechetical Institute was started which taught laity and clergy how to teach catechesis. The religious curricula and textbooks were developed by the Church and were accepted by the Ministry of National Education (now the Ministry of Education). Grades for religion class appeared on school reports; however, it was not initially included in the overall grade point average. Currently, evaluation of religion is taken into account when calculating the student grade point average.

Statistics show that the hours assigned to religion classes comprise, on the whole, many more hours than other subjects, such as chemistry, biology, and physics. At every level of education religion classes take place two hours per week. This shows the importance that is attributed to religious education, which is considered the main source of education and moral development based on Christian values.

In previous years, prior to the election of the PIS government, more and more voices were once again calling for the secularization of Polish schools (Świecka szkoła, 2016). Cries for "Liberty" or "Liberal Culture", were flowing from young liberal environments, indicating that within the whole process of education, there is much more religious instruction than lessons for other subjects (Przyłuska, 2016). Young liberals point out that the time devoted to the teaching of the Catholic religion would be better devoted to learning other, more necessary subjects. They are of the opinion that school should be free from religion, because its presence limits the religious 
freedom of non-believers to be free from religion. Young Liberals also point to the costs of religious education and are confident that these funds should be used to study other subjects and that moral issues should be left to each individual to decide for themselves. They think school should impart knowledge, not a worldview (Przyłuska, 2016). Liberal circles think that school should be neutral in terms of outlook, and base development on universal values such as, among others, human rights. Moral development should be taken care of at home with parents who are responsible for the development of the child and not at schools, whose mission is to be the transfer of knowledge and preparation for further education. Moreover, learning the Catholic religion violates the right to equal treatment for children of other faiths, because sufficient provisions have not been provided for them to study their own religion or ethics in its place.

The part of Polish society that represents traditional beliefs based on respect for tradition, which in the case of Poland is strongly associated with the Catholic Church, does not agree with this perspective. Religious instruction in schools remains the subject of debate, which has never been subjected to wider public discussion and it has never been voted on in the Sejm. The Ministry of National Education returned religion to schools in 1991. In addition, the matter is complicated by the fact that non-Catholic children do not have the opportunity to learn their religion in state schools; in this case religion should be replaced by ethics.

This is how morality became associated with religion in Poland. It seems that this association is not only erroneous but additionally adds to the possibility that the moral rebirth of Polish society after communism can only be on the basis of the Catholic Church (Majcherek, 2016).

\section{Ethics as competition for religious education}

Under the decree of the Ministry of National Education of $3^{\text {rd }}$ August, 1990 ethics was to be introduced alongside religious education for non-Catholic children. In this way ethics was introduced as an alternative to religion from the earliest years of school. In effect, children and families had two alternatives: religious education or ethics. There was no possibility of learning both. As a result of this, ethics as a subject in state schools has been recognized as an alternative to religion classes. Because students do not have the ability to choose both ethics and religion, ethics courses quickly began to be seen as competition and a kind of threat to religion classes.

The task of organizing courses in ethics rested on the shoulders of school principals. However, most parents chose religion rather than ethics and so many schools do not provide the actual possibility of ethics rather than religion. Because of this a complaint was brought before the European Court of Human Rights in Strasbourg in relation to the lack of the actual possibility of learning ethics in Polish schools. The case was given the name "Grzelak vs. Poland" because of the name of the plaintiff and in 2014 was decided in favor of the plaintiff (Informacja w sprawie zasad organizowania nauki religii i etyki, 2016). According to the European Court of Human Rights in Strasbourg's judgment the previously existing regulation on the conditions and manner of organizing religious instruction in public schools and kindergartens was changed. Under the new regulation each student must have the opportunity to study ethics in school; refusal due to an insufficient number of applicants for teaching ethics is not allowed (Dz.U. $1992 \mathrm{nr} 36$ poz. 155, 1992). In this way, the European Court of Human Rights prevented discrimination against students who wish to study ethics, not religion. Unfortunately, this does not mean, however, that since the 2014/2015 school year virtually all schools have ethics lessons.

Lesson plans also remain problematic in schools. Ethics courses are often the last lesson of the day, and religion lessons fall in the middle of the day. A student not attending religion class has free time, which he spends with another class or in the school common room (Burda, 2016). 
Similarly the contentious issue remains as to the question of who should teach ethics. According to the regulation currently in force from 2014 ethics can be taught in primary, middle, and secondary schools by teachers who have completed degrees in ethics or philosophy, as well as graduates from other areas, but after postgraduate studies in ethics, with special professional training (Dz. U. z 2013 r. poz. 1207, 2013). It is unclear whether ethics can be taught by the same person who teaches religion. For the person who chooses to have their children take ethics instead of religion, such a solution seems unfair.

Other problems concern the textbooks and content of ethics lessons. Analysis of the core curriculum of ethics in the first three stages of learning: elementary, middle, and high school demonstrates that the task of ethics courses is the development of a person into one who is sensitive to the suffering of others and conscious of the value of the natural environment. First of all, one is to be a decent person who is able to work for the common good, not a demanding egoist (Podstawa programowa edukacji wczesnoszkolnej w zakresie etyki, 2016).

Education and moral development, which in Poland is identified with religion or ethics, basically ends with the completion of the third stage of education, which is the completion of secondary school (technical college or high school). In non-humanities areas of higher education moral development is treated marginally. In programs of study first year students have the opportunity to select a lecture on ethics or philosophy but for no more than 30 hours in a semester and often even less than that. Moral development is treated similarly within humanities. There is a program of study in ethics, increasingly in professional ethics, but only for a limited number of hours. It is also considered as a matter of exceptional importance. In recent years due to the growing deficit of ethics in public life in Poland interest in ethics has increased and it has become possible to study ethics at undergraduate and graduate levels. Post graduate courses in ethics have become popular because a person who has completed a degree in humanities can obtain a post graduate qualification to teach ethics in school or in private practice as an ethics consultant to private firms.

Despite the growing popularity of ethics, codes of conduct and ever higher levels of knowledge about professional ethics, the number of ethical problems is not decreasing but increasing, and awareness of the importance of ethical issues in Polish society is still quite low. The situation has not improved in the existing public opposition between ethics and religion classes in school.

\section{Development in the life of the family}

An important and very controversial element of education and moral development in Poland is sex education. In the Polish education system, this topic is covered in the subject entitled "education for family life", which is a non-obligatory subject according to the 2014 amendment (Dz.U. 2014 poz. 395, 2014). Education for family life (abbreviated WDZ or WDR) as a school subject appeared in the education system as a result of the Regulation of the Ministry of National Education and Sport of 12 ${ }^{\text {th }}$ August 1999 (Dz.U. 1999 Nr 67 poz. 756, 1999). The Regulation introduced the subject in Polish schools beginning in the fifth grade. Its task was to provide knowledge about human sex life, parenthood, family values and contraception. Prior to 1999, sex education was held in the framework of educational lessons, sometimes biology classes, or religion; however, it was usually only a few hours of talks.

Since its introduction in schools, teaching the content of WDZ has become the subject of intense discussion. Criticism continues as to the presentation of philosophy and in what way to discuss specific topics. Neither for the most deeply believing Catholic nor for the most worldly liberal does the subject not properly execute the task of sex education. While the core curriculum 
of the subject is not objectionable its implementation invariably encounters two essential kinds of criticism. From the liberal side the subject is criticized for being too conservative in its worldview, the presentation of the traditional division of roles and responsibilities at home (the image of women as primarily mothers, cooking and cleaning), too little knowledge about contraception and homosexuality, etc. is recognized as a problem. The criticism from Catholic circles claims the exact opposite; the presented worldview is too liberal, which threatens the family; woman are presented in a way that leaves aside her true role and importance as a mother, it promotes homosexuality and artificial contraception, etc. They believe it should be abandoned as the material covered is unnecessary and harmfully sexualizes children.

WDZ is not a compulsory subject, however children automatically participate in the classes unless they are released on the basis of a written statement from the parents that they do not want their children to participate in this type of activity. This solution has been adopted by the Ministry due to the recognition of the fundamental and primary role of parents in education and moral development, including sex education of the child. WDZ classes are not very popular among children, especially the older children in high school. Students often drop out of classes so they can have time for other activities. Sex education in Poland remains effectively an open-ended problem.

\section{Education focused on profit}

Modern education is experiencing problems not only in Poland. Martha C. Nussbaum has diagnosed a worldwide crisis in education and advocates democratic education and not for the broadly understood education focused on profit, which in her opinion is the cause of the current and spreading crisis. The narrow understanding of profit gives importance only to those activities in the field of education which translates into economically measurable profits (Nussbaum, 2010).

The examples Nussbaum gives refer to India and the United States, but can also be applied to the education situation in Poland. According to Nussbaum democracy needs humanists, because humanists are the people who shape worldviews, are able to think critically and judge reality. Humanists do not generate direct economic benefits. These are the people who can decide what is good and what is bad, moreover, they ask themselves about what is good and about what is bad. In other words, in the process of their education they received a good basis of development and also education based on moral questions. In Nussbaum's opinion when these people are not present in the democratic order serious problems occur in the day-to-day functioning of a state (Nussbaum, 2010).

Today's education in Poland seems to be understood as profitable in economic terms and humanistic education, including moral development, is treated as secondary and is basically seen as not very necessary. This is evident especially in the lesson plans of students, in which the number of hours of study in subjects such as art, music education, and even history has been reduced in recent years. In accordance with the recommendations from the Ministry of National Education the director of the school must have several hours which could be used for these compulsory subjects, allocated to the study of those subjects, which in his opinion, should be taught more widely. During the three years of middle school there are fifty-five hours of study and by high school it is dropped to thirty hours (Wyjaśnienia, 2016). These hours in most cases, are used to study science or a foreign language. According to the new core curriculum in force in Polish schools since 2014, the number of hours for history lessons has been reduced (Bracisiewicz, 2016). The result is not only a lack of in-depth knowledge about the history of their own country, but also increasingly less interest in historical studies. The lack of the 
knowledge of one's own history is also undesirable for democracy - democracy lives on and functions in particular conditions which arise in the course of its development and of which it alone is not able to produce or to support by its existence (the Boeckenfoerde paradox) (Byrska, 2005).

\section{Conclusion}

Education and moral development in Poland is based primarily in public education institutions with a large proportion of participation from the Catholic Church, which is responsible for the teaching of religion. There is an observable lack of moral education in higher education. Courses in ethics are offered on a limited basis and ethics is often seen as competition to the Christian worldview. While it is possible to study ethics as a field of study these studies, however, are seen as more elitist than philosophical.

Education seems to be focused on profit, according to Martha C. Nussbaum's analysis, as narrowly understood in economic terms. The general opinion in Poland is that humanities are considered studies that do not lead to a good profession and are useful only for a general education. In actuality humanities are perceived as a kind of very useful luxury, but they do not translate directly to the possibility of earning a living. The orientation toward education for profit understood in a narrow sense, according to Nussbaum, leads to various kinds of problems, including the functioning of democracy, because it is education in humanities that provide the basic skills necessary to be a citizen and to the belief that people are equal, regardless of material status, earning opportunities, etc.

In theory, as well as in actual law, moral education in Poland is guaranteed to all. However, the teaching of ethics, the lessons of which are held only in a few schools and only as an alternative to religion classes, remains problematic. There is no possibility to take both religion and ethics. Moreover, education and moral development is equated with the teaching of religion or ethics, and ethics itself is often seen in the public eye as a kind of competition for religion.

The subject of education for family life has been controversial because of the type and method of transmitting the content, which remains a topic of discussion for both Catholics and liberals alike. These lessons are not compulsory, and parents of students who do not want them to attend this type of class must submit the relevant written statement.

There is a growing interest in ethical codes and professional ethics in Poland. Critics stress, however, that the popularity of professional ethics in Poland is caused primarily by the possibility of raising the prestige of a company which introduces a code or is subjected to ethical certification. On the other hand, the growing popularity increases awareness, which is still quite low, of ethical issues and thus supports the moral education of Polish society.

The main institution, which has for centuries been considered to be responsible for moral education in Poland is the Catholic Church, which although less popular than in the 1990s is still an important moral institution in Poland. The teaching of religion - the main tool of moral education in Poland - remains the responsibility of the Church. Moral education of children and young people who are not Catholic is left in the hands of their parents.

Joanna Mysona Byrska is the head of the Chair of social philosophy and politics at the Department of Philosophy, The Pontifical University of John Paul II in Krakow. She conducts research in social philosophy and applied ethics. She is co-editor of the series Ethics and public life. 


\section{Corresponding author:}

Joanna Mysona Byrska, Department of Philosophy, The Pontifical University of John Paul II in Krakow, ul. Kanonicza 9, PL-31-002 Kraków (Poland)

email: joanna.mysona.byrska@upjp2.edu.pl

\section{References}

BRACISIEWICZ, J. (2012): Historia w podstawie programowej kształcenia ogólnego. Wskazówki dla dyrektorów szkół [History in the general core curriculum: Tips for head teachers]. [online], [Retrieved: April 16, 2016]. Available at: https://www.bc.ore.edu.pl.

BURDA, K. (2016): Wyprowadzić religię ze szkół [Remove religion from schools]. [online], [Retrieved: April 16, 2016]. Available at: http://polska.newsweek.pl/lekcje-religii-a-lekcje-etykiczy-religia-powinna-byc-obowiazkowa-,artykuly,359659,1.html.

BYRSKA, J. (2005): Demokratyczne państwo prawa $i$ jego znaczenie dla czlowieka w myśli Ernsta -Wolfganga Boeckenfoerde [Democratic state of law and its meaning for man in Ernst-Wolfgang Boeckenfoerde's Thought]. Kraków: PAT

COGIEL, M. (2016): Krótki rys historyczny katechezy w polskiej szkole po drugiej wojnie światowej [A brief history of catechesis in the Polish school after World War II.]. [online], [Retrieved: April 16, 2016]. Available at:

http://www.opoka.org.pl/biblioteka/T/TA/TAK/historia_katechezy.html.

Dz. U, nr. 95, poz. 425: [online], [Retrieved: April 16, 2016]. Available at:http://dziennikustaw.gov.pl/du/1991/s/95/425.

Dz. U. 1999 Nr 67 poz. 756 (1999): [online], [Retrieved: April 16, 2016]. Available at: http://isap.sejm.gov.pl/DetailsServlet?id=WDU19990670756.

Dz. U. 2014 poz. 395 (2014): [online], [Retrieved: April 16, 2016]. Available at:

http://isap.sejm.gov.pl/DetailsServlet?id=WDU20140000395.

Dz. U. Nr 36, poz. 155, z późn. zm. (1992): [online], [Retrieved: April 16, 2016]. Available at: http://isap.sejm.gov.pl/DetailsServlet?id=WDU19920360155.

Dz. U. z 2013 r. poz. 1207, (2013): [online], [Retrieved: April 16, 2016]. Available at: http://isap.sejm.gov.pl/DetailsServlet?id=WDU20130001207.

GOWIN, J. (1995): Kościót po komunizmie [Church after communism]. Kraków: Znak. [online], [Retrieved: April 13, 2016]. Available at: http://liberte.pl/swiecka-szkola-projekt-ustawy/.

INFORMACJA w sprawie zasad organizowania nauki religii i etyki w roku szkolnym 2014/2015 [Information on the principles of organizing religious education and ethics in the school year 2014/2015]. [online], [Retrieved: April 13, 2016]. Available at:

https://men.gov.pl/ministerstwo/informacje/informacja-w-sprawie-zasad-organizowania-naukireligii-i-etyki-w-roku-szkolnym-2014-2015.html.

MAJCHEREK, J. (2016): Etyka to nie religia [Ethics is not a religion]. [online], [Retrieved: April 16, 2016]. Available at: http://wyborcza.pl/1,75515,8033364,Etyka_to_nie_religia.html.

MARIAŃSKI, J. (2016): Przynależność do Kościoła katolickiego w świetle sondaży opinii publicznej [Belonging to the Catholic Church in the light of public opinion polls]. [online], [Retrieved: April 13, 2016]. Available at:

http://www.opoka.org.pl/biblioteka///IK/wam_2011_kat_pol_03.html.

NUSSBAUM, M. C. (2010): Not For Profit: Why Democracy Needs the Humanities. Princeton: Princeton University Press.

PODSTAWA programowa przedmiotu wychowanie do życia $\mathrm{w}$ rodzine [The base course syllabus education for life in family]. [online], [Retrieved: April 13, 2016]. Available at: https://men.gov.pl/wp-content/uploads/2011/02/4i.pdf. 
PRZYŁUSKA B. (2016): Obywatelska Inicjatywa Ustawodawcza Świecka Szkoła podsumowanie - rationale. [online], [Retrieved: April 16, 2016]. Available at: http://liberte.pl/obywatelska-inicjatywa-ustawodawcza-swiecka-szkola-podsumowanie-rationale/. PODSTAWA PROGRAMOWA EDUKACJI WCZESNOSZKOLNEJ W ZAKRESIE ETYKI [The core curriculum of early childhood education in the field of ethics]. [online], [Retrieved: April 16, 2016]. Available at:https://men.gov.pl/wp-content/uploads/2011/02/4h.pdf.

WISŁOCKI, J. (1977): Konkordat polski z 1925 roku: zagadnienia prawno-polityczne [Polish Concordat of 1925: the legal and political issues]. Poznań: UAM.

WYJAŚNIENIA DOTYCZĄCE LICZBY GODZIN DO DYSPOZYCJI DYREKTORA SZKOŁY, KTÓRE MOGĄ BYĆ PRZEZNACZONE WYŁĄCZNIE NA OBOWIĄZKOWE ZAJECCIA EDUKACYJNE [Explanations on the number of hours available to the school principal, which can only be used for compulsory education classes]. [online], [Retrieved: April 16, 2016]. Available at:https://men.gov.pl/zycie-szkoly/ksztalcenie-ogolne/ramowe-planynauczania/wyjasnienia-dotyczace-liczby-godzin-do-dyspozycji-dyrektora-szkoly-ktore-mogabyc-przeznaczone-wylacznie-na-obowiazkowe-zajecia-edukacyjne.html.. 